\title{
'We had to be off by sundown': Narungga contributions to farming industries on Yorke Peninsula (Guuranda), South Australia
}

\section{Belinda Liebelt, Amy Roberts, Clem O'Loughlin and Doug Milera}

\begin{abstract}
Aboriginal peoples around Australia have played a significant role in the establishment and development of many of the country's successful agricultural industries. Despite this, Australian rural histories rarely acknowledge or celebrate Aboriginal people's labour as an important contributing factor in the prosperity of agricultural ventures. This lack of recognition is often symptomatic of more widespread absences that exist within Australian historical discourse regarding Aboriginal people's working lives since European colonisation. ${ }^{1}$ These absences are often at their most pronounced in rural areas, where there has been a strong desire to erase any contrary evidence that could undermine 'the pioneer success story' or challenge the idea of European settlers as anything other than guileless agents engaged in 'a struggle over adversity that became the foundation stone of nation building'. ${ }^{2}$ Increasingly, however, these mediated absences are being contested as a greater emphasis is placed on documenting and including Aboriginal people's historic and lived experiences within farming and pastoral industries around the country. ${ }^{3}$ One of the objectives of these studies has been to highlight how Aboriginal and non-Aboriginal people's lives are often
\end{abstract}

See Healy 1997; Reynolds 1999; Rose 1991; Stanner 1969.

Birch 2005: 187 - see also Fox and Phipps 1994 for more commentary on the European enterprise to reconfigure history.

3 See Boyoi and Walker 1991; Brock 1995; Gill and Paterson 2007; Harrison 2004; Jebb 2002; May 1983; McCann 2005; McGrath 1987; Paterson 2005; Shaw 1986. 
entangled, helping to negate narratives that presuppose Aboriginal people's exclusion and separation from greater Australian working life. ${ }^{4}$ Finding ways to accurately represent the specificities of these cross-cultural 'entanglements' in appropriate ways for both cultural groups has been an ongoing challenge.

\section{Silence and sharing: Challenging dominant histories to represent entangled pasts}

In the wake of 'reconciliation' movements from the late 1990s, academics have sought to promote research projects that help to bridge the perceived divides between Aboriginal and non-Aboriginal people's histories. ${ }^{5}$ Following criticism that Australian heritages and histories often reflect racial segregationist conventions rather than challenge them, ${ }^{6}$ efforts to record the "shared ${ }^{7}$ experiences of colonialism in Australia have increased. For example, Harrison ${ }^{8}$ has examined 'shared' histories and associated landscapes between Aboriginal and non-Aboriginal Australians in pastoral New South Wales. Whilst warning against the production of 'trite and overly simplified historical truism[s]' regarding these combined cross-cultural approaches, Harrison has argued that a greater emphasis on the mutual or cross-cultural aspects of pastoral narratives can assist to elucidate 'a relationship between the deep prehistory of Australian Aboriginal people and the mutual histories of Aboriginal and non-Aboriginal people working and living together after $1788^{\prime} .{ }^{10}$ In this regard, the term 'shared' for Harrison 'comes to mean 'mutually constitutive' rather than 'agreed', and includes the bad as well as the good' . ${ }^{11}$ This contrasts with the work of McBryde, who questioned whether shared heritage is an achievable or desirable goal. Instead, McBryde argued that we consider shared heritage as a 'matter of sharing the process of understanding differing viewpoints and working to accommodate them'.$^{12}$ Comparatively, McNiven and Russell have argued that categorising the contact period as 'shared' is problematic in both its terminology and conceptual implications. ${ }^{13}$ Russell maintained that the concept of 'sharing' suggested an 'invitation to participate' and ideas of 'common possession and even common enjoyment', which can deny the reality that Aboriginal peoples were rarely

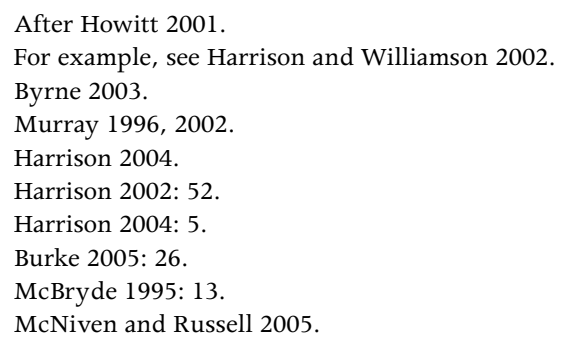


offered such courtesies. ${ }^{14}$ Attwood, through reference to the works of Rowley, Reynolds, Read and Chakrabarty, too, has provided significant exegesis of the 'shared history' concept and reiterates a primary question - how can a past be shared when Aboriginal and non-Aboriginal peoples profoundly disagree on the narrative ${ }^{15}$ Other researchers have bypassed these complications, such as Macfarlane (through reference to the work of Thomas ${ }^{16}$ ), who contends that we should understand such histories as 'entangled' rather than shared, in an effort to highlight various 'interactions between people, objects and the physical and historical characteristics of a place through time' ${ }^{17}$

For the most part, debates around 'sharing' are deeply tied to enduring national themes around Australian cultural identity and the contested ownership of the past. ${ }^{18}$ These broader themes are not explored exhaustively in this paper; however, they are relevant in the context of contesting dominant historical narratives within agricultural settler spaces. In this article, we grapple with this challenge through an exploration of the 'mutually constituted'19 local farming narratives on Yorke Peninsula (Guuranda), South Australia (Figure 1), between Narungga Aboriginal people and non-Aboriginal settlers and their descendants, paying close attention to both the communal and differing experiences that Narungga people have experienced in agricultural regions. We do this by specifically privileging the memories and voices (deployed as quotes) of Narungga people, as well as non-Aboriginal local farmers who have worked with and/or employed Narungga people. In doing so, we aim to contribute to the increasing body of research that highlights Aboriginal people's roles and experiences in the establishment and development of Australia's agricultural enterprises. Further, we work to directly challenge the mediated absences that exist in rural regions that work to erase Aboriginal people's histories, voices and distinctive experiences in Australian agricultural contexts.

14 Russell 2006: 59.

15 Attwood 2005: 246-48 - see also Chakrabarty 2001; Read 2000; Reynolds 1999; Rowley 1970.

16 Thomas 1991.

17 Macfarlane 2010: 363.

18 For an overview, see Colley 2002.

19 Burke 2005: 26; Harrison 2004. 


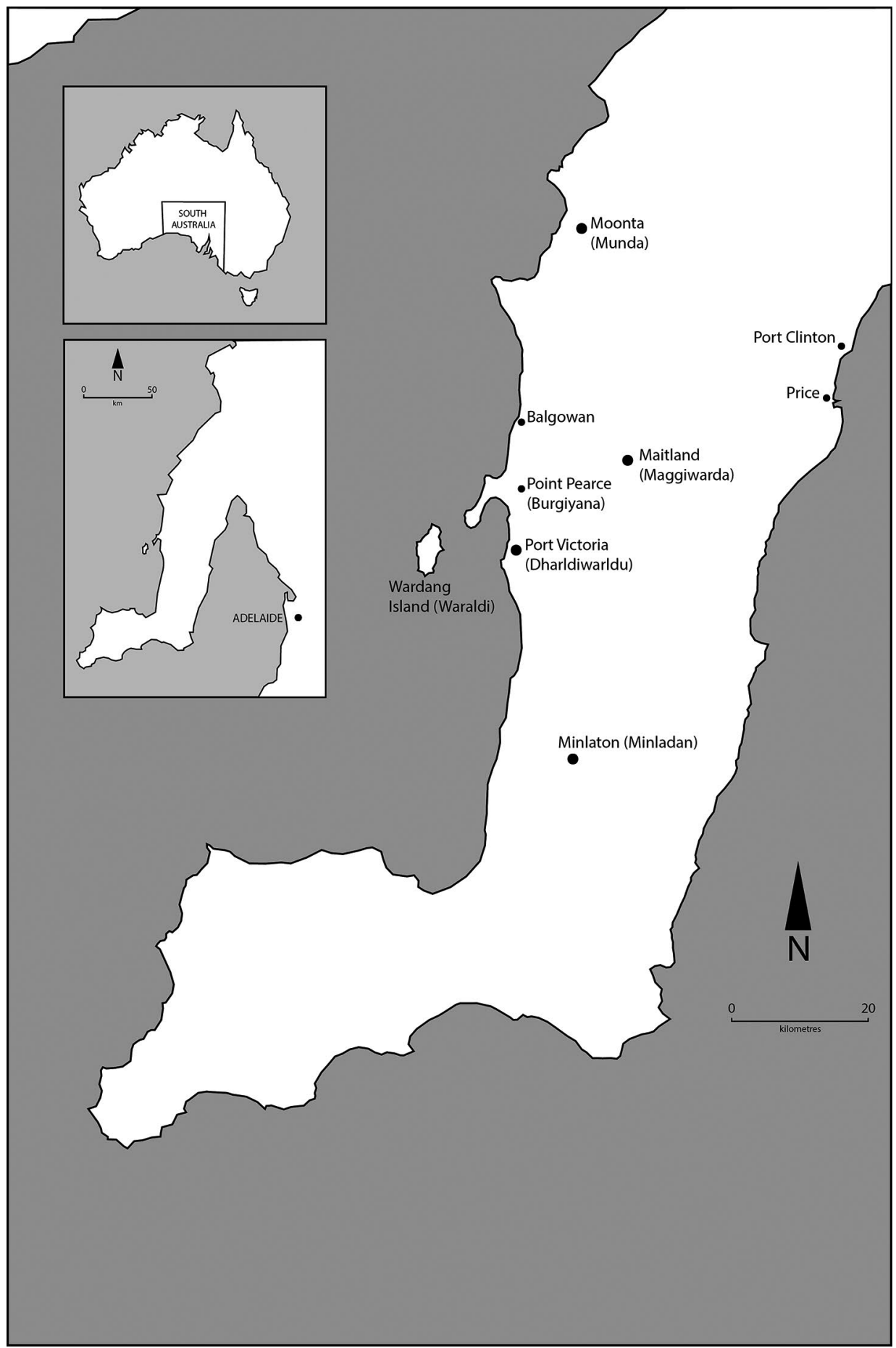

Figure 1: Yorke Peninsula (Guuranda) and relevant placenames.

Source: Produced by Belinda Liebelt. 


\section{At odds with reality: Yorke Peninsula (Guuranda) local histories}

Many of the local published histories produced about Yorke Peninsula (Guuranda) are emblematic of narratives that characterise Australian rural regions. ${ }^{20}$ These histories tend to commemorate the creation of a 'settled' agricultural landscape, and document various local farming milestones, achievements and inventions. ${ }^{21}$ Simultaneously, they tend to overlook or downplay stories of agricultural demise or economic downturn. ${ }^{22}$ Gill, Paterson and Kennedy have suggested that public histories such as these tend to "transcend nostalgia" and form a body of public history in which the values of the dominant "whitefella culture" are reaffirmed and made available as history' ${ }^{23}$ Concomitantly few of these histories document the differing experiences of Narungga people throughout the initial colonisation period, nor the ongoing consequences of European incursions into Narungga land. Similarly, these histories fail to document the contributions that Narungga people have made to farming on Yorke Peninsula (Guuranda), an absence that tends to reinforce notions that Aboriginal people are not a part of agricultural life.

Whilst the 'elaborate exercise of historical facadism' ${ }^{24}$ may have resulted in dominant settler histories, a number of publications written by or in collaboration with Narungga people do exist. ${ }^{25}$ These often provide further detail about Narungga people's agricultural pursuits; however, such narratives are often enmeshed in the greater experiences of colonialism for Indigenous Australians and are rarely celebratory or commemorative in tone. Other 'archaeological' texts (often written by amateur researchers) ${ }^{26}$ provide a wealth of information on Narungga people's material culture, but due to the era in which they were written tend to view Narungga people as 'prehistoric' rather than as a dynamic population with an agricultural history and ongoing working lives. As a result, most public local histories of Yorke Peninsula (Guuranda) relegate Narungga people to the past, or confine them geographically to Point Pearce Aboriginal Mission (Burgiyana). ${ }^{27}$ As in many parts of the country, the juxtaposing narratives that align farming 'progress' with Aboriginal demise or absence perpetuate deeply held myths of Narungga people's 'extinction' in the

20 For examples, see Carmichael 1973; Cook 1975; Heinrich 1972, 1976; Neumann 1983.

21 Gill et al. 2005.

22 Davison and Brodie 2005; Griffiths 1987.

23 Gill et al. 2005: 125.

24 Birch 2005: 188.

25 See Graham and Graham 1987; Wanganeen 1987; Krichauff 2011; Fowler 2015; Roberts et al. 2013, 2014.

26 E.g. Hill and Hill 1975.

27 See Howitt 2001; Lydon and Burn 2010; Nash 1984. 
face of agricultural development. ${ }^{28}$ As will be demonstrated, these narratives are often at odds with the reality of the continuous Narungga occupation of Yorke Peninsula (Guuranda) and the significant contributions to farming work by Narungga people.

\section{'We do most earnestly wish to be self- supporting': Share farming at Point Pearce Mission (Burgiyana) and Wardang Island (Waraldi)}

Whilst we commemorate the contributions of Narungga people to agricultural work on Yorke Peninsula (Guuranda), we must also acknowledge that initial instructions in farming labour formed part of greater attempts to Christianise and assimilate Aboriginal peoples into European economies. Victorian-era attitudes often aligned agriculture with Christianity, and saw agricultural cultivation as ordained by God. ${ }^{29}$ Settlement of the country required that the 'wild' and 'ungodly' Australian bush be 'tamed' through cultivation and the bringing of Christian values, a 'civilising' experiment that also included Aboriginal peoples. ${ }^{30}$ Further, training Aboriginal peoples as labourers and servants was integral to the attempted establishment of social hierarchies within Australia, in order to provide a class system that would separate those who owned land (and consequently power) with those employed in modes of production. ${ }^{31}$ Within these hierarchies, labour contributions by women, the working class and ethnic or Indigenous minorities were often hidden within the landscape. ${ }^{32}$

On Yorke Peninsula (Guuranda), this line of thinking is apparent in the writings of Archibald who records that the early mission activities (prior to the establishment of Point Pearce Aboriginal Mission [Burgiyana] in 1868) were undertaken to 'give them [Narungga people] not only religious instruction but also to accustom them to regular work'. ${ }^{33}$ Further, efforts to assimilate Narungga people also reflected European motivations to restrict and confine Aboriginal peoples to mission environments, and remove their presence from the newly settler-occupied landscape. Indeed, Archibald bemoans Narungga people's 'roving propensities' and 'seemingly aimless migration', which he viewed as the 'base ingratitude and selfishness' of Narungga people towards

\footnotetext{
Gill et al. 2005.

Cronon 1995; Merchant 2003, 2006.

Davison and Brodie 2005; Lydon 2009; Steele 2010.

Griffin 2000.

Bender and Winer 2001.

Archibald 1915: 10.
} 
the then missionary, Rev. W. Julius Kühn. ${ }^{34}$ Archibald also suggests that local non-Aboriginal residents' primary motivation for the initial establishment of a mission was due to a 'willingness to do something to ameliorate the hardships and privations of the wandering heathen natives in their neighbourhood' ${ }^{35}$ While benevolence may be understood as one incentive for such charity, there is little doubt that the establishment of a mission could also work to attempt to remove Aboriginal peoples from European view, as well as employ them in daily engagements and efforts that would serve to convert the landscape into a white settler space.

Subsequent to the establishment of the Point Pearce Mission (Burgiyana) in 1868, Narungga people increasingly resorted to living within its confines because (according to a visitor to the mission in 1872) they were 'being driven off their hunting grounds by the progress of the agricultural settlements' of the European settlers. ${ }^{36}$ Thus, over time, Narungga people were progressively employed at the mission to undertake agricultural work, with the latter mentioned observer stating that Narungga people were paid a 'fair wage, viz., from $6 \mathrm{~d}$ to $1 \mathrm{~s}^{\prime} .{ }^{37}$ Tasks on the mission included carting posts, shearing, woolpicking, shepherding (which was often undertaken by the girls) and wheat reaping. ${ }^{38}$ Kühn records in 1875 that Narungga people were also employed at various woolsheds around the peninsula during this time and that subsequent to 'the arduous work of shearing and harvest' Narungga people would 'take a rest; hence for a time they disperse themselves through the Peninsula, visiting different parts where may be friends are to be found, and where they can enjoy fishing, which is to them a great pleasure'. ${ }^{39}$ These accounts suggest that Narungga people were often able to travel to and from the mission as required, while partaking in agricultural work when and if they chose. ${ }^{40}$ As time went on, agricultural labour increasingly became a form of control over Aboriginal peoples through wages and exclusion (i.e. at Point Pearce [Burgiyana]) and/or a means of survival.

In 1913 a different view of fair wages and work emerges in the 'Progress Report of the Royal Commission on the Aborigines'. This South Australian-based investigation was designed to inquire into and provide a report upon 'the control, organisation and management of the institutions in this State [South Australia] set aside for the benefit of the aborigines [sic] ${ }^{\prime}$, ${ }^{41}$ and ultimately recommended that all the Aboriginal missions within the state be taken over by the government, and that compulsory training be undertaken by all Aboriginal peoples at all

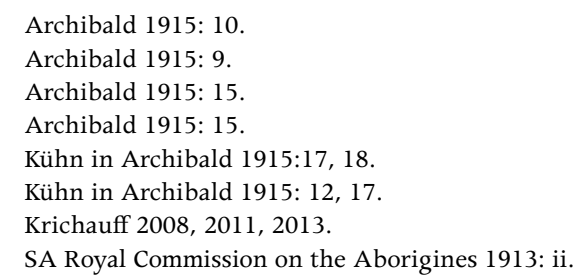


institutions to prepare them for labouring and service work..$^{42}$ One useful aspect of the royal commission was that it recorded important Aboriginal perspectives on farm work. For example, under examination Alfred Hughes said of farm work at Point Pearce Aboriginal Mission (Burgiyana): 'I have had my nose to the grindstone the whole time. Meaning that I have had to work hard' ${ }^{43}$

Hughes also suggested he was unhappy with the share farming system, in which white farmers from the surrounding Yorke Peninsula (Guuranda) district were working land (within the mission boundaries) which had been specifically set aside for Narungga people. He says 'we are not satisfied with the present conditions and would prefer to work the land on our own if the Government would help us'.$^{44}$ Similarly, both Alfred Hughes and William Adams made it clear that they opposed white farmers who had taken over the farming business at the mission and argued that the work should be given back to Aboriginal people. ${ }^{45}$ In regards to farming work more generally, William Adams, Joe Edwards and Walter Sansbury all indicated that the work and conditions were unacceptable, and the money available to them was barely enough to get by. ${ }^{46}$

Despite the mission being taken over by the government in March 1914 and converted to a working station, this does not seem to have improved the situation in the eyes of local Aboriginal people. ${ }^{47}$ In 1924 residents of Point Pearce (Burgiyana) wrote a letter to the Rev. J.C. Kirby, again, requesting that they be given fair wages for work and areas of land in their own name. Kirby submitted this letter to the Adelaide Register, where it was published on Saturday 21 June 1924:

We do most earnestly wish to be self-supporting. About 15 years ago, when our trustees in Moonta had the management of this mission, we asked them for a portion of this land. They refused to give us what we asked for. We felt we were not doing any wrong, when we asked for a portion of this land: we were only asking for our right. We will never be any better off as long as we remain on this mission. We have some fine men and women here, who can hold their own with any white people. We would like you to come and see the work that is done here by our own people. We have our own masons here, also carpenters. We have practical farmers also, but for all the work that is done by our own people the wages are not good enough. The single men are paid at the rate of 5/ per day, the married men 8 / per day. Some of our married men get $6 /$ or $7 /$ per day, then out of that small wage they have to find their wives, children, and them selves in everything. Every winter the wages are reduced. A shilling is taken off every man's wages down here, but they won't cut the prices in our store. The things we get in our mission store are not first class, but they charge us top prices for

42 SA Royal Commission on the Aborigines 1913: ix.

43 SA Royal Commission on the Aborigines 1913: 112.

44 SA Royal Commission on the Aborigines 1913: 112.

45 SA Royal Commission on the Aborigines 1913: 117.

46 SA Royal Commission on the Aborigines 1913: 115-20.

47 Mattingley and Hampton 1988:199-200. 
them. We have got to pay for our meat. The meat and flour are grown on our land. We would nearly all of us like to have a portion of this land, or if the Government cannot give us land here we would like them to lease the land to us, then we can feel that we are independent, not living on charity. There are several white farmers here at present in halves with the mission, taking the bread out of our mouths. Our people here, with large families, feel it most, with the scanty wages that they receive weekly.

Later, Graham and Graham also wrote about the work and wages of earlier times, indicating that there was plenty of work and that wages were paid, but argue that they were minimal:

The people also used to do a lot of shearing, bag sewing, lumping and crutching away from the Mission. They also used to do shearing, reaping of wheat and barley and bag sewing on the Mission. It was a paying concern in those days. After they'd done the work on the Mission, they'd work for the white share farmers and bag sewers, lumping the wheat down at Balgowan. Well, shearing was around about September, and then up until nearly Christmas, they'd reap and sew the bags. There was plenty of work, working for a wage, but it wasn't much money.$^{48}$

In the 1930s, Norman Tindale observed aspects of Narungga people's involvement in farm work. ${ }^{49}$ He suggests that much of the farming on Point Pearce (Burgiyana) was undertaken by the residents; however, he notes that it was conducted under the supervision of Superintendent Bray via a share farming system in which the men contracted for the station work and could only receive a percentage of the sales. Tindale wrote 'for with his [Superintendent Bray's] system it is possible, as no where else in Australia, to secure, from trained natives, work equal to that of whites'.$^{50}$ Similarly, other observers noted the skills of station residents; for example, an overview of farming progress in the Maitland (Maggiwarda) district appeared in the Adelaide Observer on Saturday 17 July 1926, and stated:

The natives are employed principally in agricultural work, and many of them are experts in shearing, wool classing, road making, fencing, building, carpentering, blacksmithing, painting, and indeed all work pertaining to farm life in all its departments.

By Narungga people's own words and through the evidence of observers, it seems clear that Narungga people took great pride in agricultural vocations. It also appears that, on numerous occasions, Narungga people fought hard to gain freedom and economic advancement through such work, as well as ownership over land in their own right. Under strict mission/governmental controls that

48 Graham and Graham 1987: 23.

49 Tindale 1938-39: 797.

50 Tindale 1938-39: 797. 
sought to regulate every aspect of Aboriginal labour, it seems this was impossible to obtain. Despite this structural inequality, white observers often viewed the agricultural work that Aboriginal peoples undertook as a continued route to assimilation. In regards to the share-farming situation at the mission, Tindale wrote: 'in it may lie the future of the halfcastes [sic] during the period of their adjustment to life amongst whites'. ${ }^{51}$ Thus, while European commentators saw Narungga people's working contributions as evidence of successful assimilation and as fulfilling the state's requirement for affordable labour, Narungga people are more likely to have understood agricultural work as a possible means of maintaining connection to their land and remaining on country, while earning a living and gaining increased independence over their lives.

\section{'They all want their bags sewed at once': Narungga memories of farming work}

By the turn of the twentieth century, Narungga people were participating in various agricultural economies throughout the entire peninsula, including (but not limited to) ploughing, seeding, reaping, threshing, fencing, dam sinking, quarrying stones, sump and stone clearing, tank and drain excavation, general farm work, milking, butchering and boundary riding, care of sheep, cows and pigs, and carting grain, superphosphate and stores. ${ }^{52}$ Later, however, as farms were more established and sheep and cereal cultivation became dominant local industries, demand for Aboriginal labour became especially high for specific tasks such as shearing and bag sewing on farms around the peninsula (Figure 2). The latter industries, in particular, have allowed Narungga people to maintain connections to their country well beyond Point Pearce (Burgiyana) boundaries. Indeed, access to country provided by this work was particularly crucial in the era before the Aborigines Act 1934-1939 (SA) was repealed in 1962. ${ }^{53}$ Just as earlier generations of Narungga people had done, Narungga people in the midtwentieth century would often combine other cultural pursuits in the course of participating in agricultural work, such as traditional fishing activities and the monitoring of significant places. ${ }^{54}$ Further, shearing and bagging labour on farms provided a level of freedom away from the mission/station in which Narungga people were able to move about the countryside without the same level of scrutiny or restriction that was often applied by the strict regimentation of mission/station life. ${ }^{55}$ Unfortunately however, not all segregation conventions could be avoided, as is explored further below.

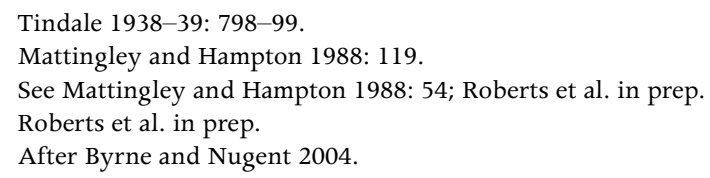




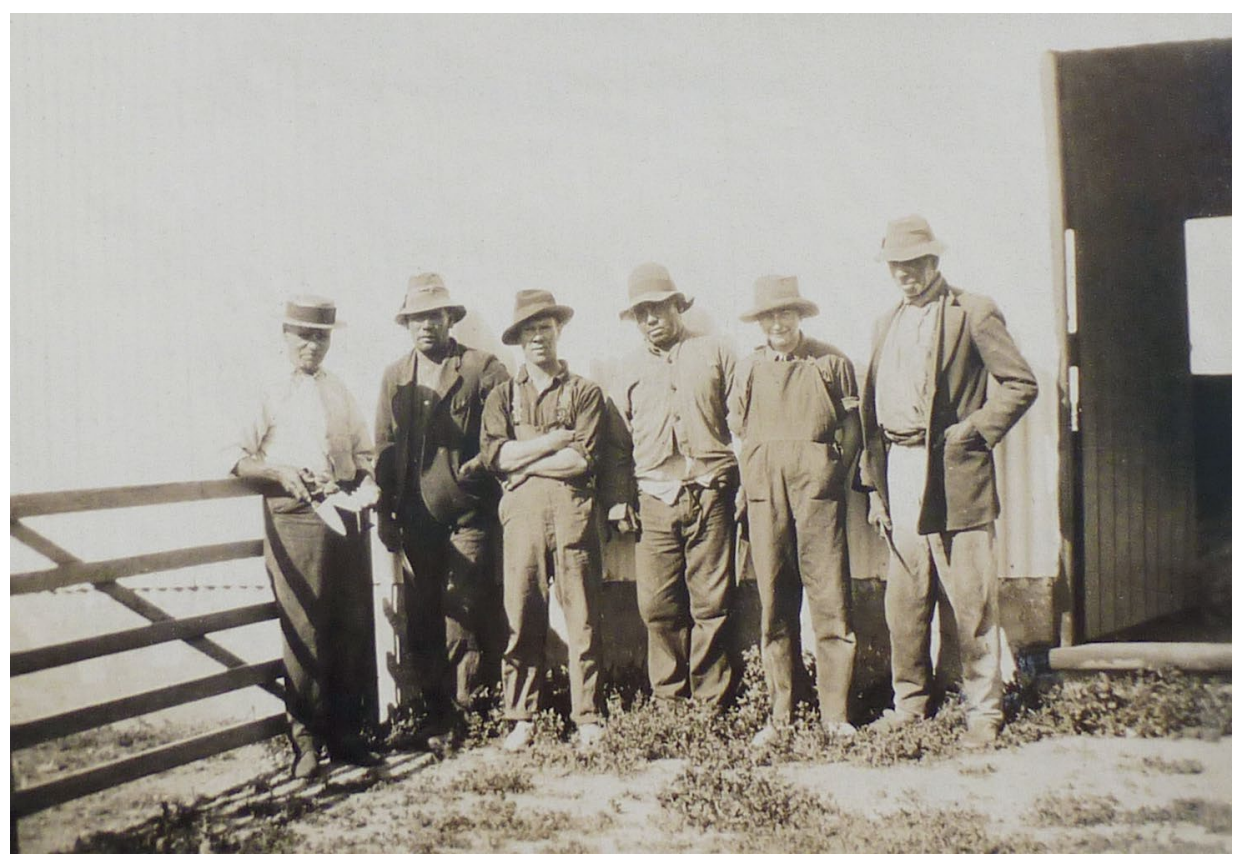

Figure 2: Aboriginal and non-Aboriginal blade shearers working together at the Moody shearing shed (Innisfail) near Port Victoria (Dharldiwarldu) in 1928.

Left to right: George Reid, Lionel Hughes, Harry Richards (shed hand), L. Adams, Sam Moody and Tom Adams.

Source: Courtesy of S. Moody.

The working life of Narungga Elder Clem O'Loughlin provides insights into the ways that Aboriginal people lived and worked on Yorke Peninsula (Guuranda) in the mid-twentieth century. ${ }^{56} \mathrm{O}^{\prime}$ Loughlin worked as a shearer his whole adult life, starting when his father (Alfred O'Loughlin, also a shearer) introduced him to the work.

BL: Sounds like you shore for a lot of different people?

CO: Yeah, started Moonta for the Cooper's when I was 15, old Charlie Cooper. Five miles out of Moonta, south towards Point Pearce. Was my first shed. Was battling then, 28 I got on my first day, 28 for the next three days. Gee my back ached! Then I got to, you know near the Cooper's there. I went to school with some of their kids, old Charlie Cooper's kids. But that's back in the '40s, or '50s? '50s. I left school in '48, when I turned 14. I was out the door then.

BL: And you were shearing until 1979, 1980?

56 See Mattingley and Hampton 1988: 48-49; Roberts et al. 2013: 89. 
CO: Yeah, did a lot of days shearing. I didn't like it at first. My back was aching all the time. Then I got used to it. Then I went looking for shearing. Had a little stint down at Clarry Hoyle's at Minlaton, he was looking for shearers. I remember him saying, 'Clem, he's no trouble let's go and get him'. I wasn't a good shearer, but you know I used to get my 100 a day. That's why they wanted me to go down there. I'd help them finish it off too, by doing a neat score every day. When they wanted me to help finish the sheep off I just took my own package, made them work till five o' clock.

BL: Why did you stop shearing?

CO: I spent long enough shearing. I think maybe my back gave in, or something like that. Cos I shore at Point Pearce too. We needed to get permission to go there and shear the sheep. See how like white man then, I had my exemption, I wasn't on the mission, I was allowed to go in the pub, but others wasn't. Yeah.

And I lived down in Hollywood for a while, you know Hollywood? I had a little one room shack there cos I wasn't allowed on Point Pearce. So me and my wife and my two kids I had then, I was shearing from there. Then I bought a little bungalow in Moonta, three bedroom miner's cottage. I don't know what I got for it, it was cheap anyhow. ${ }^{57}$

As O'Loughlin explains, because he was exempted, both his contribution to agricultural life on the mission/station and his residential choices were restricted. "Exemption" was a legislative provision under the Aborigines Amendment Act $1939^{\prime 58}$ which was an 'invidious form of discrimination' that ultimately had the effect of declaring certain Aboriginal individuals and families as 'honorary whites' and was sometimes used as a punitive measure by the Aborigines Protection Board against a person's will. ${ }^{59}$ Indeed, O'Loughlin's exclusion from life at Point Pearce (Burgiyana) had profound consequences beyond his agricultural/residential life and extended into his family life, particularly during the time when he was prohibited from visiting his wife at the mission/station (as she was not exempted). ${ }^{60}$ Thus, he was forced to live at Hollywood (a small settlement just outside of the Point Pearce [Burgiyana] boundaries, occupied primarily by Narungga people who had been exempted or excluded from the mission), until he saved enough to buy property in Moonta (Munda).

O'Loughin's experiences of the Aborigines Protection Board contrast with those Aboriginal people at Point Pearce (Burgiyana) who were not exempted. Whilst O'Loughlin had to live within the strictures of forced assimilation, those on the mission/station were suffering under segregation. ${ }^{61}$ The 'arrogance was vast'

57 Clem O'Loughlin interview with Belinda Liebelt, 15 July 2013.

58 Roberts et al. 2013: 89.

59 Mattingley and Hampton 1988: 48.

60 Roberts et al. 2013: 89.

61 See Reynolds 2000: Chapter Six for a summary of these views and their sway. 
for both regimes and the European 'self-confidence quite invincible' - 'black should imitate white' or be otherwise 'confined to the fringes of society' ${ }^{62}$ In reality, individuals like $\mathrm{O}^{\prime}$ Loughlin had to endure the effects of both regimes: the (unsuccessful) attempt to remove him from Narungga society simply resulted in the segregationist curfews also impacting his own working life because he worked in cooperation with Point Pearce (Burgiyana) men - thus the 'off before sundown' rule applied:

BL: When you were driving around going shearing, did you just go shearing or did you ever do any other work?

CO: Oh we did other work in between. Maybe all the people we shore for, I sewed their bags at the end of the year, got all their bags sewn. Because I had up to 40,000 bags there one year to sew. And then I had to go to Point Pearce, and pick up shearers, ah sewers. Take out six to eight at a time. Because they all want their bags sewed at once, anna [true!].

I used to get permission to go there, because I wasn't allowed on Point Pearce see, I got an exemption. We wasn't allowed there, we lived in Moonta, because we moved out. They said I can live up there without coming to Point Pearce, we had to get permission to come to Point Pearce, to pick up our bag sewers and our shearers. We had to be off before sundown, hard to do in the winter time. We was doing shearing around that time, when the sun was going down. Away from home for 12 or 13 hours a day. Because of that, from Moonta you know, took me an hour to get down there, shear for 8 hours, and then head back. Tough. I had my family in Moonta. But, it worked out alright in the end. Kids went to school in Moonta. ${ }^{63}$

And:

CO: Mostly Wanganeens and my brother Edmund O'Loughlin he was there [at Pine Point lumping wheat], Arthur Wanganeen. Cos they used to lump for all the ketches that came in there. I used to be out in the middle of the peninsula right - sewing all the bags, all the wheat bags and the barley bags. I had a little gang of sewers - come from Moonta - I used to pick my sewers up from Point Pearce, about six of them and take them out sewing, because I wasn't allowed out there before sunrise [due to exemptions]. I used to pick them up - I was supposed to drop them off before sundown, but some nights you used to sew bags until 10 or 11 o'clock, because the bag gets too tough. We had to stay out late to finish them ... Since I left school I been sewing bags - I had all those farmers I would shear sheep for ... Didn't get much to sew 100 bags anna [true!]. We used to get raw and sunburnt working. The first day you had blisters ... We used to live at Balgowan too - when dad was lumpin' wheat there. The catchers used to come round to load up off the jetty. Cause dad [Alfred O'Loughlin] used to shear for a couple of people around there. ${ }^{64}$

62 Reynolds 2000: 233-34.

63 Clem O'Loughlin interview with Belinda Liebelt, 15 July 2013.

64 Clem O'Loughlin interview with Amy Roberts, 24 March 2006. 
Despite these challenges, $\mathrm{O}^{\prime}$ Loughlin recalls that there were many good times, and explained that farmers rarely treated him poorly. In particular, O'Loughlin remembers friendly employers such as the Hoyles near Minlaton and the Whittakers north of Maitland, who he worked with for over 10 years. However, as is evident below, O'Loughlin's mostly positive memories of the farmers are tempered with the 'Balgowan Walk Off': ${ }^{65}$

BL: I was wondering what do you think about back then, compared to now?

CO: Back then was tougher than it is now. If you got a shed down there them days you was lucky you got a shed. But because we worked at Whittakers, we had them every year for the next 10-12 years. Didn't have to go looking for shearers. They used to come past pick us up on a Monday morning, drop us off on a Friday night. Bed and breakfast paid for.

BL: Did you ever get treated badly, or mostly okay?

CO: There was this shed up at Balgowan, not the Moody's maybe Frank Gregory's, anyway one day Uncle Diver [Cedric Varcoe] and some other Nhanggas [Aboriginal people] walked off the job - didn't think they were getting paid enough. They had to get someone to pick them up.

But when I start work at half past seven I expect to finish at half past five. Get your full eight hours in you know. To make your 20 pound a day, 40 dollars whatever it was. No I never had no arguments with any of them. They were good people around that area. And a lot of us used to go to Minlaton too. Blokes used to come out Monday, looking around, driving around the streets, looking for shearers. Clarry Hoyle, I don't know how you spell that. He had a depot shed down there (with a six stand plant). ${ }^{66}$

In these interview excerpts, the extent of O'Loughlin's movements across the Yorke Peninsula (Guuranda) are reflected in the many places he mentions throughout the district (Figure 1). Not included in these excerpts, O'Loughlin also speaks about shearing on the eastern side of the peninsula near Port Clinton, and also travelling off country for work, north of the Yorke Peninsula (Guuranda) ${ }^{67}$ as well as 'cherry picking' (picking stones out of the paddocks and putting them on a pile) for minimal wages for Eugene Maloney at Maitland (Maggiwarda). ${ }^{68}$ In relation to other agricultural activities, O'Loughlin also recalled that his brother Edmund and father Alfred also shore sheep in competitions at the Maitland Show. ${ }^{69} \mathrm{O}^{\prime}$ Loughlin's memories provide a critical insight into how Aboriginal people contributed to agricultural ventures throughout the mid-twentieth century in rural South Australia.

65 This is the only oral history available we are aware of that details this event - more investigation about the circumstances that led to it would be beneficial.

66 Clem O'Loughlin interview with Belinda Liebelt, 15 July 2013.

67 Clem O'Loughlin interview with Belinda Liebelt, 15 July 2013.

68 Clem O'Loughlin, pers. comm. with Amy Roberts and Belinda Liebelt, 2 March 2016.

69 Clem O'Loughlin, pers. comm. with Amy Roberts and Belinda Liebelt, 2 March 2016. 
Tangible evidence, too, remains of Narungga contributions to agricultural life - such as Clem O'Loughlin's hook and his brother's (Michael O'Loughlin) needle for bag sewing (Figure 3). Such seemingly functional objects become 'entangled' when considered in the context of the stories told in this paper. Indeed, as Macfarlane argues, the 'concept of entanglement that Thomas develops' encourages us to 're-think what is involved in people's exchanges' thus emphasising the "mutability of things in recontextualisation", rather than any fixed or single properties of identity or function'.$^{70}$ Concepts around the entanglement of tangible objects in cross-cultural exchanges on Yorke Peninsula (Guuranda) are being explored by Liebelt as part of a broader project.

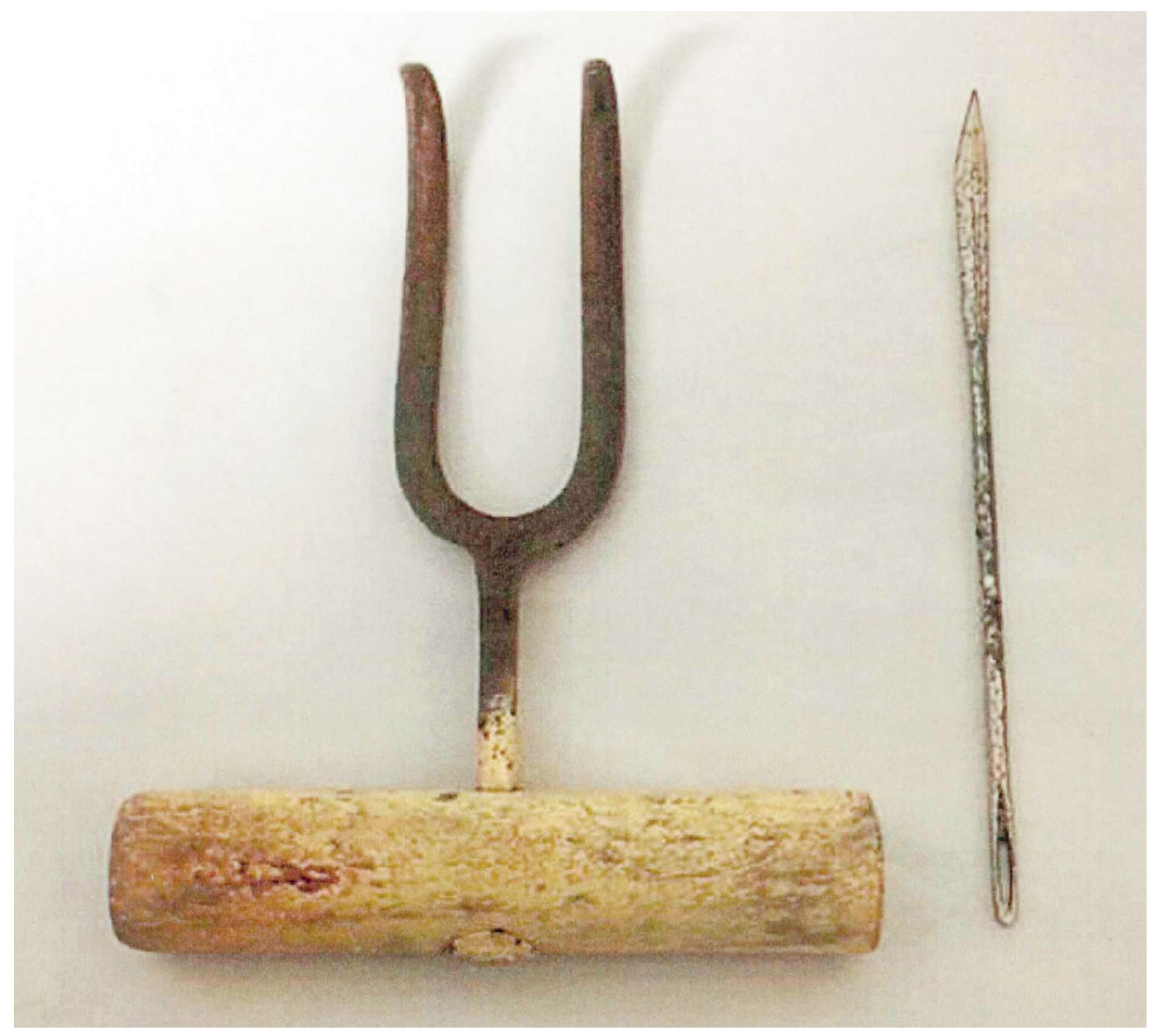

Figure 3: Clem O'Loughlin's hook and his brother's (Michael O'Loughlin) needle for bag sewing.

Source: Courtesy of M. O'Loughlin. 


\section{'I expect probably most places had them': Memories from non-Aboriginal farmers}

Narungga people's participation in agricultural labour across the peninsula has thus provided various settings for cross-cultural interactions between Aboriginal and non-Aboriginal people that may have otherwise not taken place. Speaking with local settler-descendent farmers, a number of individuals remember having Aboriginal shearers on their properties. One long-time resident (Jill Carmichael), living north of Minlaton (Minladan), remembers that Aboriginal shearers worked in many of the bigger shearing sheds around the region:

Well I certainly remember when there were a lot of the Aboriginal shearers, because they used to be at Hoyle's shearing shed. That was the big, a big shearing shed that people [from around the area] did thousands of sheep ... Often there were Aboriginal shearers used there. And then there were others that used them, I know, as well; we called it Kings. And they used to have Aboriginal shearers there. I expect probably most places had them. ${ }^{71}$

Similarly, Bob Edwards, whose grandfather lived alongside the Aboriginal man Charlie Adams on the Edwards property, ${ }^{72}$ also remembers employing Aboriginal shearers on their property from the late 1940s onwards. Here he recalls interactions between himself and some of the shearers, including Will Varcoe and Barney Warrior:

BE: In the 1940s, oh it would have been about 1948, we couldn't get shearers and the chap that was doing the shearing said would you take a team of natives and Dad said yeah they'll be alright. So they arrived, three natives, to shear and of course they were on good tucker, they did about half speed. Best shearing we'd ever had really. But they made it last.

They were a mighty lot. I used to take them back each weekend and Dad always said, if you are offered a cup of tea you drink it if it killed you, you know, don't refuse it. And I had many cups of tea when I got up there. Poor old Will [Varcoe] had only dirt floors and that but everything was spotless really.

BL: Do you remember the names of any of those old shearers?

BE: Yeah Will Varcoe. Barney Warrior. Who was the other one? Well he was the oldest of them. Barney Warrior's a bit shorter. I can't think of the other one...$^{73}$

In the passage above, Edwards alludes to the differing social conditions that Aboriginal peoples often had to endure, suggesting differences in the availability of good food and home comforts. ${ }^{74}$ Later in the interview, Bob Edwards also

71 Jill Carmichael interview with Belinda Liebelt, 26 July 2013.

72 Parsons 1987.

73 Bob Edwards interview with Belinda Liebelt, 12 May 2014.

74 See also Mattingley and Hampton 1988: 200. 
gives an example of how relationships between white farmers and Aboriginal shearers could be reciprocal at times, recalling how his father gifted a horse trap and harness to the Aboriginal men after the shearing was completed, so long as they returned the horse that they used to take it away:

When it came time to go, they wanted the trap we had there. We weren't using it ... so Dad said well you can take it, take it home. They wanted the harness as well so he gave them the harness. And they said well what about a horse? Dad said well you can take the horse too but just let him go when you finish. So they drove him up there and let him go and about two days later the horse is back home again [laughing]. ${ }^{75}$

Of course, relationships between Aboriginal and non-Aboriginal people could also involve tensions. While Clem O'Loughlin suggests that relationships between white farmers and the Narungga people working for them were usually on good terms (with the exception of the remembered 'Balgowan Walk Off'), ${ }^{76}$ it seems apparent that at times the differences between Aboriginal and non-Aboriginal people's lives have resulted in misunderstandings. As noted above, O'Loughlin recalls how difficult it was to travel across the peninsula, gain entry to Point Pearce (Burgiyana) under the exemption system, and pick up other shearers to arrive at the sheds early in the morning. Non-Aboriginal people on Yorke Peninsula (Guuranda), who often have had little insight into the strict controls that Aboriginal peoples have been forced to live under, might not conceive of why 'sticking to times' may be difficult. During the interview with Jill Carmichael, she spoke with another farming local in the district (via telephone) who also remembered working with Aboriginal shearers. Carmichael recalls the discussion:

JC: He just said to me about working for Hoyle's when he was a real young boy. That was his first job and he went working for Hoyle's and in the shearing shed. And he said it was a very difficult process with them [Aboriginal people] because he said Monday morning you knew you'd lose half a day because you know, they were no good at sticking to times. And he said, you didn't know how many would turn up. You had no idea.

Sometimes a team would turn up and another time it would only be half of them [Aboriginal people] turn up, or a couple, or something like that, you see. And so he said it was very difficult working with them, because you know they just, well, what would you say? They didn't have any concept of time or didn't want to have any concept of time. You wouldn't know which it was. To try and keep them [Aboriginal people] to any sort of a routine was a very difficult situation ... But, they were very good shearers. Very, very good shearers. ${ }^{77}$

75 Bob Edwards interview with Belinda Liebelt, 12 May 2014.

76 Clem O'Loughlin interview with Belinda Liebelt, 15 July 2013.

77 Jill Carmichael interview with Belinda Liebelt, 26 July 2013. 


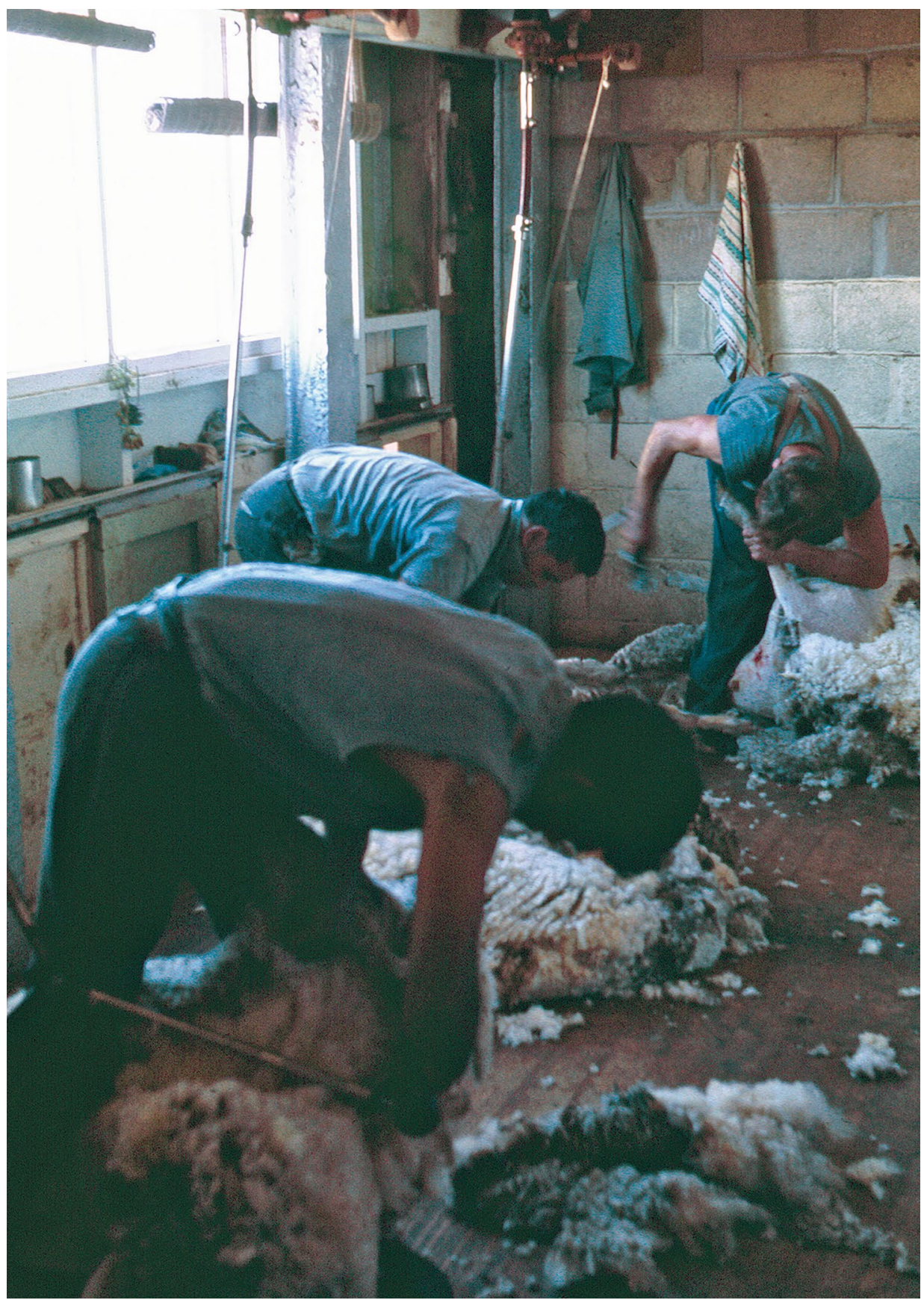

Figure 4: Front to back: Wellesley Sansbury, Clem O'Loughlin and Barry Will shearing at the Moody shearing shed, near Port Victoria (Dharldiwarldu) in 1963.

Source: Courtesy of S. Moody. 
This contrasts with Clem O'Loughlin's recollections, as he suggests he was never late. He explains here why at times though, some shearers may have been late coming from Point Pearce (Burgiyana) as they had difficulties securing transport from the mission:

We were always on time, never late. Well I wasn't. Sometimes they were late coming from Point Pearce, sometimes they haven't got a car, and they looking around for a ride and all that. We were right on tap, cos we had our own car, and even when we shore with Barry Will, we were right on time with him too. ${ }^{78}$

Above, O'Loughlin mentions Barry Will, a local white shearer with whom he had a good working relationship for many years. O'Loughlin explained how Will often assisted him (and Wellesley Sansbury) to get shearing contracts with local farmers. ${ }^{79}$ Pictured in Figure 4 at the Moody shearing shed near Port Victoria (Dharldiwarldu), Will, Sansbury and O'Loughlin worked around the peninsula together in the 1960s and '70s. These cross-cultural relationships, between both Aboriginal and non-Aboriginal shearers, as well as the farmers who employed them, demonstrate the complexity of the entangled histories that we examine.

\section{'You couldn't get work you know': Changing times in the mid-twentieth century}

In the excerpts above, O'Loughlin explained how he gave up shearing in the late 1970s, because of a sore back (a common shearing ailment). It was likely that it was also because times were changing and shearing work was much more difficult to secure. This timing coincides with a change in agricultural economies after the mid-twentieth century. While both World War One and Two and the Depression impacted wool prices, demand and labour negatively on Yorke Peninsula (Guuranda), by the 1950s the local agricultural industry was booming again..$^{80}$ Overall, however, the importance of agricultural industries in Australia began to decline throughout the second half of the twentieth century, as agricultural economic income slipped within a century from a quarter of the country's output to approximately 4 per cent of the economy. ${ }^{81}$ Further, changes to the way that agriculture was practised, with advancing technology and mechanised processes for cereal cultivation, meant that demand for additional farm labour was decreasing. This, combined with higher wages for labourers, meant that securing farming work was increasingly difficult. Doug Milera grew up at Point Pearce (Burgiyana) in the 1950s and '60s, and watched his uncles

78 Clem O'Loughlin interview with Belinda Liebelt, 15 July 2013.

79 Clem O'Loughlin interview with Belinda Liebelt, 15 July 2013.

80 Yorke Peninsula Visitor Information Centre 2014: 71.

81 Davison and Brodie 2005. 
coming and going from Point Pearce (Burgiyana) for farming employment in the local district. However, when it came time to find work for himself, the changed conditions of the late 1960s and '70s meant that farming work was increasingly scarce. Here, Milera explains the compounding reasons as to why Narungga people found it difficult to find agricultural work:

Growing up at Point Pearce, I went to school at Maitland. Getting work when I left school was difficult because you know, because you just couldn't wander into Maitland and get a job because obviously it was, say for example, farmers, they had their own kids to provide an income to as well. You couldn't get a job in a local store ... And during those days there was tension, there was racism, and so people from Point Pearce, not didn't ordinarily fit in, I mean, going back to the history of the old days of the initial set of Point Pearce and there after, there was links with the wider community where there was football and people did work on farms during those days because it was a time when you know, I guess labour was cheap to build a farm you really had to have labour to do that. And so people from Point Pearce were utilised and right back to the mission days when people were trained as domestics and farm hands and they would then be sent to go and work on local properties, surroundings properties. During the era that I grew up in, the '60s and '70s. During the '70s you couldn't get work you know. I basically had to leave the community. I joined the army that was my way of getting out of Point Pearce, to fight to actually make it in the big wide world sort of thing, so to speak. ${ }^{82}$

Above, Milera refers to the tensions felt between people living in Maitland (Maggiwarda) and Point Pearce (Burgiyana) as one of the contributing reasons as to why it was difficult for Aboriginal people to secure rural work during this period. His observations resonate with research undertaken by Wundersitz, who in 1979 conducted a spatial study into prejudice on Yorke Peninsula (Guuranda), focusing specifically on Maitland (Maggiwarda) and Port Victoria (Dharldiwarldu) regions. Wundersitz argued that it is important to consider the 'complex inter-relationship between cultural, social, physiological and locational factors operating within a definite spatial or environmental framework' when considering studies into prejudice. ${ }^{83}$ Her findings suggested that a considerable degree of social separation existed between Aboriginal and white people at the time of study, with mutual distrust and suspicion on both sides. Wundersitz argued that the tensions she observed had arisen as a result of a single outstanding feature to the region; the residential proximity of a segregated Aboriginal reserve in the study area. ${ }^{84}$ She argued that the segregation of Aboriginal people had led to a situation where Aborigines and whites have lived adjacent to, but have nevertheless remained essentially separate from, each other since

82 Doug Milera interview with Belinda Liebelt, 31 August 2012.

83 Wundersitz 1979: 3.

84 Wundersitz 1979: 294. 
the first days of settlement' ${ }^{85}$ Thus, the combination of segregation factors ${ }^{86}$ that contribute to racism in the region, along with decreasing demand for agricultural labour during the second half of the twentieth century, resulted in reduced Narungga participation in agricultural work. As a consequence, one of the primary settings for rural cross-cultural relationships between Narungga people and non-Aboriginal people on Yorke Peninsula (Guuranda) has diminished. Comparatively, while the latter mentioned economic farming pressures were also experienced in the wider non-Aboriginal community, for local Aboriginal people, these economic factors must be considered in context with local histories of exemption, segregation and prejudice.

\section{Conclusions: Cross-cultural entanglements and agricultural practice}

The results of our explorations into the entangled histories between Narungga and non-Aboriginal people on Yorke Peninsula (Guuranda) suggest that these two cultural groups do 'share' stories/histories, in the sense that there are many common elements appearing in the narratives of both sides. However, there are some serious disjunctures in the agricultural memories and experiences of the Aboriginal and non-Aboriginal people interviewed in this research, which, we argue, arise out of the ongoing legacies of residential race segregation and structural discrimination, which are contextual to the specific agricultural region that we examine.

The perceived notion that Narungga people should largely be confined to 'mission life' as compared to the wider locally celebrated and agriculturally based 'country life' must be acknowledged as an ongoing contributing factor toward the tensions between (some) non-Aboriginal and Aboriginal people on Yorke Peninsula (Guuranda). The reality of continuous Narungga occupation, of Narungga presence throughout the landscape, and of the many similar historic and lived experiences working in agricultural vocations, tend to be offset by Narungga people's differing experiences of geographic and social segregation and structural discrimination over many years. These injustices often impacted on people's daily working (and personal and cultural) lives and their capacity for

\footnotetext{
85 Wundersitz 1979: 294.

86 Such factors extended beyond residential segregation to include other aspects of daily life - such as drinking [alcohol consumption], as already noted, as well as other facets such as medical segregation. Indeed, Clem O'Loughlin recalled how Aboriginal women were not allowed to have their babies at the Maitland Hospital but instead had to travel a much longer distance to give birth at Wallaroo (Wadlawaru) (pers. comm. with Amy Roberts and Belinda Liebelt, 2 March 2016).
} 
economic self-development. Such structural inequalities are only emphasised when examining the various ways that Narungga people have contributed to agricultural industries in the local district.

At the same time, by exploring the historic and lived experiences of Narungga people's working lives on Yorke Peninsula (Guuranda) it is also possible to reveal the ways that many non-Aboriginal and Aboriginal people interacted in the agricultural domain - with cordial accommodations often developing for the sake of economic benefit, whilst in some cases more respectful and trusting cross-cultural relationships were formed. The many entanglements between non-Aboriginal and Aboriginal people's working lives are illustrative of the actualities of agricultural practice in Australia, and narratives that reveal crosscultural engagements and cultural contact between people over time. Exploring the multifaceted and entangled nuances of these cross-cultural relationships can help to elucidate existing local histories on Yorke Peninsula (Guuranda) in greater detail, transparency and accuracy for both Aboriginal and nonAboriginal people living together in the district now and into the future.

\section{Notes on Narungga toponyms}

Traditional Narungga toponyms (using the current orthography from the Narungga Aboriginal Progress Association) ${ }^{87}$ are included in this paper alongside European placenames at the request of the Narungga community. Indeed, we should not forget that the naming of places is always power laden. ${ }^{88}$ Further, it should be remembered that European naming throughout the country has played a key role in the 'colonial silencing of [I]ndigenous cultures' ${ }^{89}$ By incorporating Narungga placenames for country, we acknowledge the entanglement of European and Aboriginal geographies that exist throughout Yorke Peninsula (Guuranda) and the ways in which these entangled geographies come to be known and named over time by both Aboriginal and non-Aboriginal peoples throughout Australia. ${ }^{90}$ 


\section{Acknowledgements}

The authors would like to thank the non-Aboriginal contributors from Yorke Peninsula (Guuranda) who assisted with this paper, including Bob Edwards, Jill Carmichael and Stuart Moody. This research would not be possible without the approval, ongoing support and guidance of the Narungga Aboriginal Committee Regional Authority, the Narungga Nation Aboriginal Corporation, Point Pearce Aboriginal Corporation and the Adjahdura Narungga Heritage Group. In addition to the Narungga community members who collaborated on this article, thanks go especially to Tauto Sansbury, Quenten Agius, Jeffrey Newchurch, Klynton Wanganeen, Cyril Kartinyeri, Ernie Wilson Jnr, John Buckskin, George Walker, Michael Wanganeen, Professor Lester-Irabinna Rigney, Peter Turner, Gabriel Kathleen, Jean Stengle and Michael O'Loughlin for supporting this research. Thanks also go to Jane Lydon for advice and comments on an earlier version of this paper. We also thank two anonymous reviewers and the Editor for their constructive criticism and advice.

The UWA Human Research Ethics Office granted research approval for this project on 28 February 2014 (RA/4/1/6674). This research is supported in part by the University of Western Australia Ronald and Catherine Berndt Foundation.

\section{References}

Archibald, T.S. 1915, Yorke's Peninsula Aboriginal Mission: A Brief Record of Its History and Operations, Hussey \& Gillingham Limited, Adelaide.

Attwood, Bain 2005, 'Unsettling pasts: reconciliation and history in settler Australia', Postcolonial Studies 8(3): 243-59.

Bender, Barbara and Margot Winer 2001, Contested Landscapes: Movement, Exile and Place, Berg, Oxford.

Berg, Lawrence D. and Robin A. Kearns 2009, 'Naming as norming: "Race," gender and the identity politics of naming places in Aotearoa/New Zealand', in Critical Toponymies: The Contested Politics of Place Naming, Lawrence D. Berg and Jani Vuolteenaho (eds), Ashgate, London: 19-52.

Birch, Tony 2005, "Death is forgotten in victory": Colonial landscapes and narratives of emptiness', in Object Lessons: Archaeology and Heritage in Australia, Jane Lydon and Tracy Ireland (eds), Australian Scholarly Publishing, Melbourne: 186-200. 
Boyoi, Waddi and Johnny Walker 1991, Bush Time, Station Time: Reminiscences of 80 Years, Adelaide Aboriginal Studies and Teacher Education Centre, University of South Australia, Adelaide.

Brock, Peggy 1995, 'Pastoral stations and reserves in South and Central Australia, 1850s-1950s', in Aboriginal Workers, Ann McGrath and Kay Saunders (eds), Australian Society for the Study of Labour History, Sydney: 102-14.

Burke, Heather 2005, 'Book review of Shared Landscapes: Archaeologies of Attachment and the Pastoral Industry in NSW', Archaeology in Oceania 41(1): 26-27.

Byrne, Dennis 2003, 'Segregated landscapes: The heritage of racial segregation in New South Wales', Historic Environment 17(1): 13-17.

Byrne, Dennis and Maria Nugent 2004, Mapping Attachment: A Spatial Approach to Aboriginal Post-contact Heritage. Department of Environment and Conservation NSW, Hurstville.

Carmichael, Ern 1973, The Ill-shaped Leg: A Story of the Development of Yorke Peninsula, Swift Printing Services, Stepney, SA.

Chakrabarty, Dipesh 2001, 'Reconciliation and its historiography: Some preliminary thoughts', UTS Review 7(1): 6-16.

Colley, Sarah 2002, Uncovering Australia: Archaeology, Indigenous People and the Public, Allen and Unwin, Crows Nest, NSW.

Cook, Diana 1975, The Striding Years: A History of the Minlaton District Council Area, Automatic Printing, Port Pirie.

Cronon, William 1995, 'The trouble with wilderness: Or, getting back to the wrong nature', in Uncommon Ground: Rethinking the Human Place in Nature, William Cronon (ed.), W. W. Norton \& Co., New York: 69-90.

Davison, Graham and Marc Brodie 2005, Struggle Country: The Rural Ideal in Twentieth Century Australia, Monash University ePress, Clayton, Vic.

Fowler, Madeline 2015, “"Now, are you going to believe this or not?" Addressing Neglected Naratives through the Maritime Cultural Landscape of Point Pearce Aboriginal Mission/ Burgiyana, South Australia', PhD thesis, Department of Archaeology, Flinders University of South Australia.

Fox, Paul with Jennifer Phipps 1994, Sweet Damper and Gossip: Colonial Sightings from the Goulburn and North-East, Benalla Art Gallery, Benalla, Vic. 
Gill, Nicholas and Alistair Paterson 2007, 'A work in progress: Aboriginal people and pastoral cultural heritage in Australia', in Geographies of Australian Heritages: Loving a Sunburnt Country?, Roy Jones and Brian J. Shaw (eds), Ashgate Publishing Company, Aldershot: 113-31.

Gill, Nicholas, Alistair Paterson and M. Kennedy 2005, “"Murphy, do you want to delete this?" Hidden histories and hidden landscapes in the Murchison and Davenport Ranges, Northern Territory, Australia', in The Power of Knowledge, the Resonance of Tradition. Electronic publication of papers from the AIATSIS Indigenous Studies Conference, September 2001, Graeme K. Ward, and Adrian Muckle (eds), Australian Institute of Aboriginal and Torres Strait Islander Studies, Canberra: 125-37.

Graham, Doris and Cecil Graham 1987, As We've Known It: 1911 to the Present, Aboriginal Studies and Teacher Education Centre, South Australian College of Advanced Education, Underdale, SA.

Griffin, Darren 2000, "A Christian Village of South Australian Natives": A Critical Analysis of the Use of Space at Poonindie Mission, South Australia', BA(Hons) thesis, Department of Archaeology, Flinders University of South Australia.

Griffiths, Tom 1987, Beechworth: An Australian Country Town and its Past, Greenhouse, Melbourne.

Harrison, Rodney 2002, 'Shared histories and the archaeology of the pastoral industry in Australia', in After Captain Cook: The Archaeology of the Recent Indigenous Past, Rodney Harrison and Christine Williamson (eds), AltaMira Press, Walnut Creek: 37-58.

2004, Shared Landscapes: Archaeologies of Attachment and the Pastoral Industry in New South Wales, University of New South Wales Press, Sydney.

Harrison, Rodney and Christine Williamson (eds) 2002, After Captain Cook: The Archaeology of the Recent Indigenous Past, AltaMira Press, Walnut Creek.

Healy, Chris 1997, From the Ruins of Colonialism: History as Social Memory, Cambridge University Press, Cambridge.

Heinrich, Rhoda 1972, Governor Ferguson's Legacy, Maitland-Kilkerran Centenary Committee, Adelaide.

1976, Wide Sails and Wheat Stacks, Port Victoria Centenary Committee, Port Victoria. 
Hercus, Luise, Flavia Hodges and Jane Simpson 2002, The Land is a Map: Placenames of Indigenous Origin in Australia, ANU E Press, Canberra.

Hill, David L. and Sandré J. Hill 1975, Notes on the Narangga Tribe of Yorke Peninsula, Lutheran Publishing House, Adelaide.

Howitt, Richie 2001, 'Frontiers, borders, edges: Liminal challenges to the hegemony of exclusion', Australian Geographical Studies 39(2): 233-45.

Jebb, Mary Anne 2002, Blood, Sweat and Welfare: A History of White Bosses and Aboriginal Pastoral Workers, University of Western Australia Press, Crawley.

Koch, Harold and Luise Hercus 2009, Aboriginal Placenames: Naming and Renaming the Australian Landscape, ANU E Press and Aboriginal History Inc., Canberra.

Krichauff, Skye 2008, 'The Narungga and Europeans: Cross-cultural Relations on Yorke Peninsula in the Nineteenth Century', MA thesis, School of History and Politics, University of Adelaide.

2011, Nharangga Wargunni Bugi-Buggillu: A Journey through Narungga History, Wakefield Press, Kent Town, SA.

2013, 'Narungga, the townspeople and Julius Kühn: The establishment and origins of the Point Pearce Mission, South Australia', Journal of the Anthropological Society of South Australia 37: 57-72.

Kühn, Wilhelm 1879, Adelaide Chronicle, 10 May 1879: 12.

Lydon, Jane 2009, Fantastic Dreaming: The Archaeology of an Aboriginal Mission, AltaMira Press, Walnut Creek.

Lydon, Jane and Allan Burns 2010, 'Memories of the past, visions of the future: Changing views of Ebenezer Mission, Victoria, Australia', International Journal of Historical Archaeology 14(1): 39-55.

Macfarlane, Ingereth 2010, 'Entangled Places: Interactive Histories in the Western Simpson Desert', PhD thesis, Australian Centre for Indigenous History, The Australian National University.

Mattingley, Christobel and Ken Hampton 1988, Survival in Our Own Land: 'Aboriginal' Experiences in 'South Australia' since 1836, Wakefield Press, Adelaide.

May, Dawn 1983, From Bush to Station: Aboriginal Labour in the North Queensland Pastoral Industry, 1861-1897, James Cook University, Townsville. 
McBryde, Isabel 1995, 'Dream the impossible dream? Shared heritage, shared values, or shared understanding of disparate values?', Historic Environment $11(2 / 3): 8-14$.

McCann, Joy 2005, 'The unsettled country: Landscape, history, and memory in Australia's wheatlands', in (Dis)Placing Empire: Renegotiating British Colonial Geographies, L.J. Proudfoot and Michael Roche (eds), Ashgate Publishing Limited, Hampshire: 41-60.

McGrath, Ann 1987, Born in the Cattle: Aborigines in the Cattle Country, Allen \& Unwin, Sydney.

McNiven, Ian and Lynette Russell 2005, Appropriated Pasts: Indigenous Peoples and the Colonial Culture of Archaeology, AltaMira Press, Lanham.

Merchant, Carolyn 2003, Reinventing Eden: The Fate of Nature in Western Culture, Routledge, New York and London.

2006, 'The scientific revolution and the death of nature', Isis 97(3): $513-33$.

Murray, Tim 1996, 'Contact archaeology. Shared histories? Shared identities?', in Sites. Nailing the Debate: Archaeology and Interpretation in Museums, S. Hunt and Jane Lydon (eds), Historic Houses Trust of New South Wales, Sydney: 199-213.

2002, 'Shared histories and the archaeology of the pastoral industry in Australia', in After Captain Cook: The Archaeology of the Recent Indigenous Past, Rodney Harrison and Christine Williamson (eds), AltaMira Press, Walnut Creek: 37-58.

(NAPA) Narungga Aboriginal Progress Association 2006, NharanggaWarra: Narungga dictionary, lst edn, Wakefield Press, Adelaide.

Nash, David 1984, 'The Waramungu's reserves 1892-1962: A case study in dispossession', Australian Aboriginal Studies, no. 1: 2-16.

Neumann, Beryl 1983, Salt Winds Across Barley Plains, Gillingham Printers, Adelaide.

Parsons, Allan 1987, 'Reminiscence', Journal of the Anthropological Society of South Australia 25(3): 35.

Paterson, Alistair 2005, 'Early pastoral landscapes and culture contact in central Australia', Historical Archaeology 39(3): 28-48. 
Read, Peter 2000, Belonging: Australians, Place and Aboriginal Ownership, Cambridge University Press, Melbourne.

Reynolds, Henry 1999, Why Weren't We Told?: A Personal Search for the Truth About Our History, Viking, Melbourne.

2000, Black Pioneers: How Aboriginal and Islander People Helped Build Australia, Penguin Books, Ringwood, Vic.

Roberts, Amy, Madeline Fowler and Tauto Sansbury 2014, 'A report on the exhibition entitled “Children, Boats and 'Hidden Histories': Crayon Drawings by Aboriginal Children at Point Pearce Mission (SA), 1939"', Bulletin of the Australasian Institute for Maritime Archaeology 28: 24-30.

Roberts, Amy, Jennifer McKinnon, Clem O'Loughlin, Klynton Wanganeen, Lester-Irabinna Rigney and Madeline Fowler 2013, 'Combining Indigenous and maritime archaeological approaches: Experiences and insights from the "(Re)locating Narrunga Project", Yorke Peninsula, South Australia', Journal of Maritime Archaeology 8(1): 77-99.

Roberts, Amy, Lester-Irabinna Rigney and Klynton Wanganeen (in prep.), The Butterfish Mob: Narungga Cultural Fishing, Wakefield Press, Adelaide.

Rose, Deborah Bird 1991, Hidden Histories: Black Stories from Victoria River Downs, Humbert River and Wave Hill Stations, Aboriginal Studies Press, Canberra.

Rowley, Charles 1970, The Destruction of Aboriginal Society, Australian National University Press, Canberra.

Russell, Lynette 2006, 'Shared landscapes: Archaeologies of attachment and the pastoral industry in New South Wales [book review]', Australian Archaeology 62: 58-59.

Shaw, Bruce 1986, Countrymen: The Life Histories of Four Aboriginal Men as Told to Bruce Shaw, Australian Institute of Aboriginal Studies, Canberra.

South Australia Royal Commission on the Aborigines 1913, Progress Report on the Royal Commission on the Aborigines, South Australian Parliamentary Paper no. 26, Government Printer, Adelaide.

Stanner, William 1969, After the Dreaming, Australian Broadcasting Commission, Sydney.

Steele, Kathleen 2010, 'Fear and loathing in the Australian bush: Gothic landscapes in Bush Studies and Picnic at Hanging Rock', Colloquy: Text Theory Critique 20: 33-56. 
Thomas, Nicholas 1991, Entangled Objects: Exchange, Material Culture, and Colonialism in the Pacific. Harvard University Press, Cambridge.

Tindale, Norman 1938-39, Harvard and Adelaide Universities Anthropological Expedition, Australia, 1938-1939. Journal and notes by Norman B. Tindale, vol. 2, South Australian Museum Archives AA 338/1/15/2.

Vuolteenaho, Jani and Lawrence D. Berg 2009, 'Towards critical toponymies', in Critical Toponymies: The Contested Politics of Place Naming, Lawrence D. Berg and Jani Vuolteenaho (eds), Ashgate, London: 118.

Wanganeen, Eileen 1987, Point Pearce: Past and Present, Aboriginal Studies and Teacher Education Centre, South Australian College of Advanced Education, Underdale, SA.

Wundersitz, Joy 1979, 'A Study of White Attitudes towards Aborigines in the Maitland and Port Victoria District of Central Yorke Peninsula', MA thesis, Department of Geography, University of Adelaide.

Yorke Peninsula Visitor Information Centre 2014 Farming Yorke Peninsula, Department of Sustainability, Environment, Water, Population and Communities, Adelaide. 
This text is taken from Aboriginal History, Volume 40, 2016, edited by Liz Conor, published 2016 by ANU Press,

The Australian National University, Canberra, Australia. 